\title{
World Journal of Unexpected findings at laparotomy of a
Pediatric Surgery 12-year-old girl with obstructive jaundice and choledocholithiasis: a case report
}

Felix Oyania (D) , ${ }^{1,2}$ Muriel Cleary, ${ }^{3}$ Alfred Ogwal, ${ }^{4}$ Arlene Muzira Nakanwagi, ${ }^{4}$ Nasser Kakembo, ${ }^{4}$ John Sekabira, ${ }^{5}$ Gustavo Villalona, ${ }^{6}$ Doruk Ozgediz ${ }^{7}$

To cite: Oyania F, Cleary M, Ogwal A, et al. Unexpected findings at laparotomy of a 12-year-old girl with obstructive jaundice and choledocholithiasis: a case report. World $\mathrm{JnI}$ Ped Surgery 2021;4:e000201. doi:10.1136/wjps-2020-000201

- Additional supplemental material is published online only. To view, please visit the journal online (http://dx.doi.org/10.1136/ wjps-2020-000201).

Received 29 September 2020 Accepted 26 April 2021

Check for updates

(C) Author(s) (or their employer(s)) 2021. Re-use permitted under CC BY-NC. No commercial re-use. See rights and permissions. Published by BMJ.

For numbered affiliations see end of article.

Correspondence to Dr Felix 0yania; oyafel@icloud. com
Congenital duodenal obstruction (CDO) is a relatively common neonatal anomaly with a reported incidence of 1 in 2500-10 000 live births. ${ }^{2}$ Diagnosis can be made prenatally with ultrasound (US) during antenatal care or during the postnatal period commonly as bilious vomiting and feeding intolerance. Patients with a partial stenosis can survive to present in a much-delayed fashion. ${ }^{3-6}$

Annular pancreas (AP) is a rare congenital disorder that may be clinically asymptomatic, may present as a neonatal intestinal obstruction or as a more complex pathology in adults. The incidence is reported as 1-3 in 20000 . AP may be asymptomatic ${ }^{7}$ and discovered incidentally during routine investigations for other conditions or at autopsy. Most of the cases are diagnosed either prenatally or in the first few days of life. ${ }^{8}$ If the condition is neither diagnosed prenatally nor presents with complications in early life, it may be undetected until adulthood with varying complications, such as pancreatitis or gastric outlet obstruction, thereby making the diagnosis difficult. AP may coexist with other congenital anomalies. ${ }^{38-11}$ We report a case of obstructive jaundice from choledocholithiasis due to an AP that caused duodenal stenosis and biliary stasis.

A 12-year-old girl who was referred from western Uganda presented with postprandial abdominal pain, food fear, progressive weight loss, jaundice and dark urine for 2 years. She reported often missing school due to abdominal pain. Initial US obtained by her local care providers showed dilated intrahepatic and extrahepatic ducts, a distended gall bladder and a stone in the common bile duct (CBD). The patient weighed only $32 \mathrm{~kg}$ and appeared wasted with moderate jaundice and scleral icterus during her physical exam. Her abdominal examination was unremarkable. Her initial laboratory workup showed mild anemia, no leukocytosis, significant hyperbilirubinemia with mildly elevated liver enzymes and a negative infectious workup (table 1).

She had a cardiac echocardiogram that was normal and a repeat abdominal US that again demonstrated dilated $\mathrm{CBD}$ to $2 \mathrm{~cm}$, dilated intrahepatic and extrahepatic ducts, a distended gall bladder and an obstructing stone in the CBD measuring $2.3 \times 1.5 \mathrm{~cm}$. Basing on these findings, the team elected to proceed with an exploratory laparotomy. Owing to resource limitations, magnetic resonance cholangiopancreatography (MRCP), endoscopic retrograde cholangiopancreatography (ERCP) and intraoperative fluoroscopy were not available options.

Surgery commenced through a right subcostal incision and intraoperative findings demonstrated a dilated gall bladder, cystic duct and bile duct $(2 \mathrm{~cm})$ with a palpable stone. The proximal duodenum also appeared very dilated with a patulous pylorus and a decompressed distal duodenum. After medializing the ascending and transverse colon, the duodenal obstruction was identified with an associated AP. The duodenum was adequately mobilized and freed from its retroperitoneal attachments via a Kocher maneuver. Attempted flushing of the stone through the cystic duct was unsuccessful. The CBD was therefore opened, and the stone was extracted. The residual debris was flushed, and a T-tube was placed. A diamond shaped duodenoduodenostomy was then performed with tapering of the proximal duodenum to prevent anastomotic dysfunction. The patient's recovery was uneventful at shortterm follow-up (figures 1-5). 


\begin{tabular}{|c|c|c|}
\hline Variables & Results & Normal range \\
\hline \multicolumn{3}{|l|}{ Complete blood count } \\
\hline WBC $\left(10^{3} / \mu \mathrm{L}\right)$ & 3.7 & $4-12$ \\
\hline $\mathrm{Hb}(\mathrm{g} / \mathrm{dL})$ & 11.8 & $11-14.5$ \\
\hline Platelets $\left(10^{3} / \mu \mathrm{L}\right)$ & 405 & $150-400$ \\
\hline HIV serology & Negative & \\
\hline $\mathrm{Hb}$ electrophoresis & $\begin{array}{l}\text { Normal (AA } \\
\text { type) }\end{array}$ & \\
\hline $\begin{array}{l}\text { Electrolytes- } \mathrm{Cl}^{-} \mathrm{K}^{+} \mathrm{Na}^{+} \\
(\mathrm{mmol} / \mathrm{L})\end{array}$ & Normal & $\begin{array}{l}\mathrm{Cl}^{-} 98.0-107.0 \\
\mathrm{~K}^{+} 3.5-5.5, \mathrm{Na}^{+} \\
136-145\end{array}$ \\
\hline \multicolumn{3}{|l|}{ Bilirubin $(\mu \mathrm{mol} / \mathrm{L})$} \\
\hline Total & 90 & $0-18.8$ \\
\hline Direct & 45 & $0-4.3$ \\
\hline \multicolumn{3}{|l|}{ Liver enzymes (U/L) } \\
\hline ALP & 900 & $0-270$ \\
\hline AST (GOT) & 42 & $0-35$ \\
\hline ALT (GPT) & 34 & $0-41$ \\
\hline Creatinine $(\mathrm{mg} / \mathrm{dL})$ & 0.47 & $0.0-0.7$ \\
\hline Urea (mmol/L) & 2.7 & $3-7$ \\
\hline Hepatitis B & HBsAg negative & \\
\hline
\end{tabular}

ALP, alkaline phosphatase; ALT (GPT), alanine transaminase (glutamic pyruvic transaminase); AST (GOT), aspartate transaminase (glutamic oxaloacetic transaminase); $\mathrm{Hb}$, hemoglobin; $\mathrm{HBsAg}$, Hepatitis B surface antigen; WBC, white blood cell count.

The causes of CDO may be intrinsic or extrinsic. Intrinsic causes may include duodenal atresia, stenosis or web. Extrinsic obstruction may result from malrotation with Ladd's bands, preduodenal portal vein or AP.

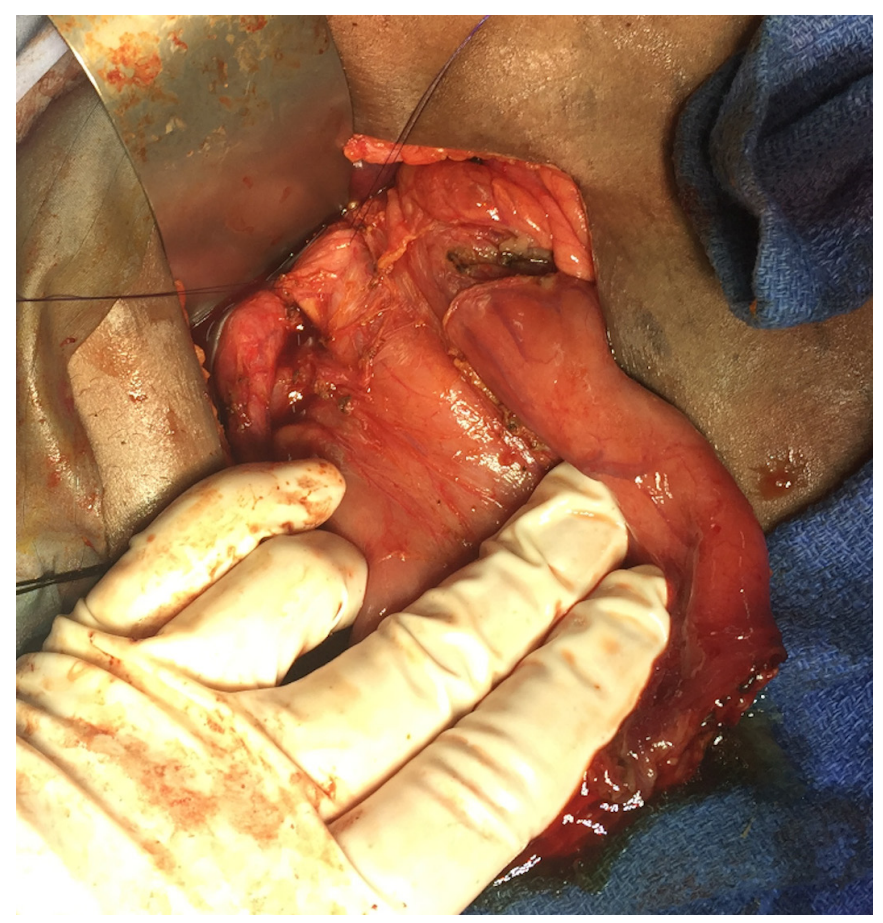

Figure 1 Bile duct and palpable stone.

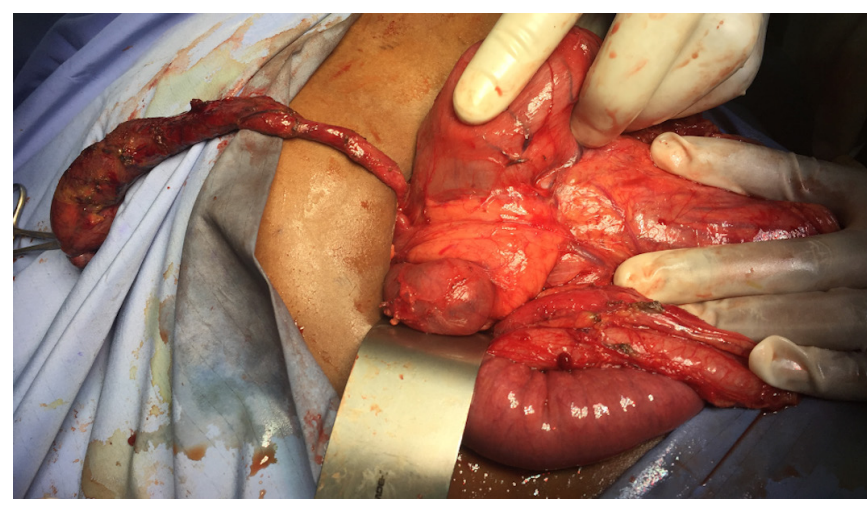

Figure 2 Dilated duodenum, patulous pylorus, decompressed distal duodenum, annular pancreas with duodenal obstruction.

Obstructions usually occur in the second part of the duodenum and are often associated with prematurity $(46 \%)$ and maternal polyhydramnios $(33 \%)$. There may be associated anomalies, including Down's syndrome $(>30 \%)$, malrotation $(>20 \%)$, congenital heart diseases $(20 \%)$ and other gastrointestinal (GI) tract and renal anomalies. ${ }^{3-6}$

AP is a congenital anomaly that can present in the neonatal period or can remain asymptomatic. ${ }^{12}$ Autopsy reports reveal an incidence of 5-15/100 $000 .{ }^{13}$ ERCP has improved the diagnosis of AP with reports as high as 1 in 150 patients undergoing this procedure. ${ }^{14} \mathrm{AP}$ was first described by Tiedemann in 1818 and was named by Ecker in $1862 .{ }^{15}$ These cases were generally found in patients who underwent surgery for duodenal atresia as an incidental finding as was the case in our patient.

Several theories have been documented to explain the embryological development of AP. ${ }^{8131617}$

AP typically presents in the neonatal period with intestinal obstruction, poor feeding, bilious vomiting (if proximal to the ampulla of Vater), non-bilious vomiting and

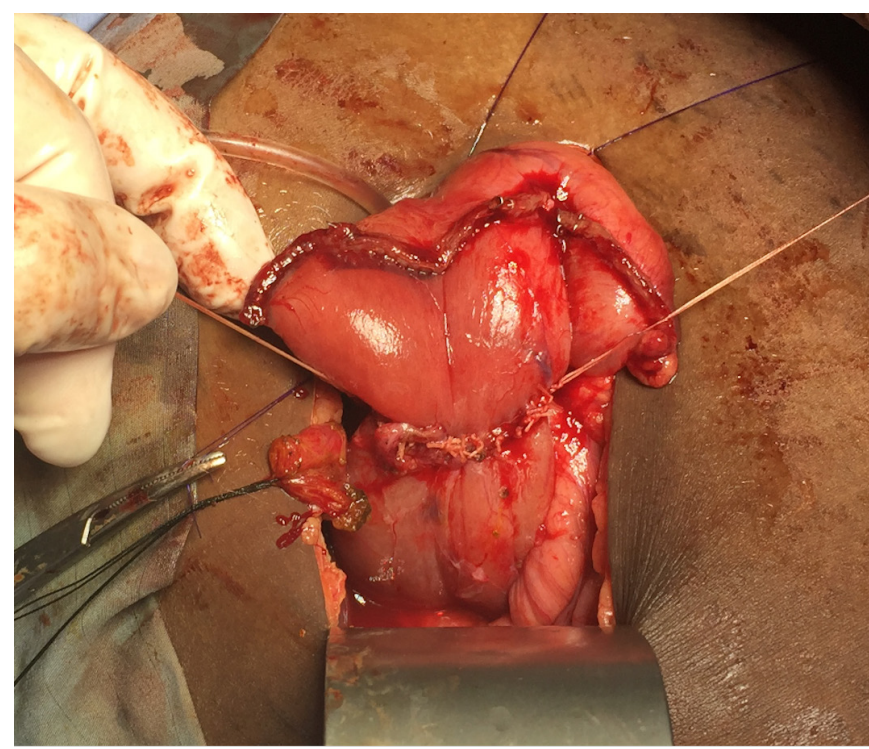

Figure 3 Duodenoduodenostomy with tapering of proximal duodenum. 


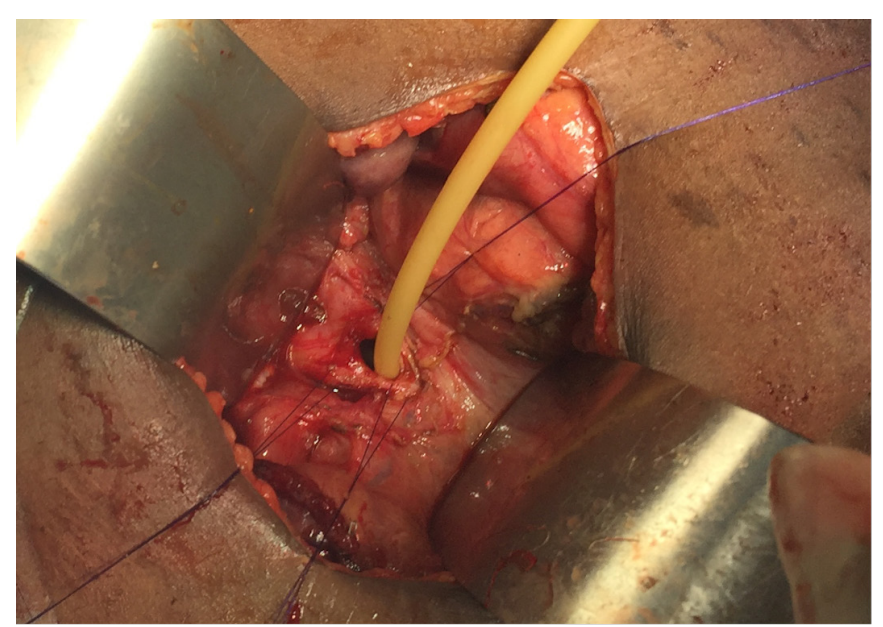

Figure 4 T-tube placement.

irritability. There may be a history of polyhydramnios 1618 if prenatal USs have been performed.

When children present in infancy or in early childhood, they have GI symptoms including poor feeding, vomiting and abdominal distention. Most of our patients in Uganda present late with malnutrition, failure to thrive, bile stained vomiting and-less frequently-abdominal cramps. Our patient presented with postprandial abdominal pain and fear of food. Adults are much more likely to describe upper abdominal pain or to present with features of pancreatitis. ${ }^{391214}$

AP can be identified preoperatively using radiological and endoscopic studies including upper GI studies, CT, MRI, MRCP or ERCP. In more than $40 \%$ of cases, the

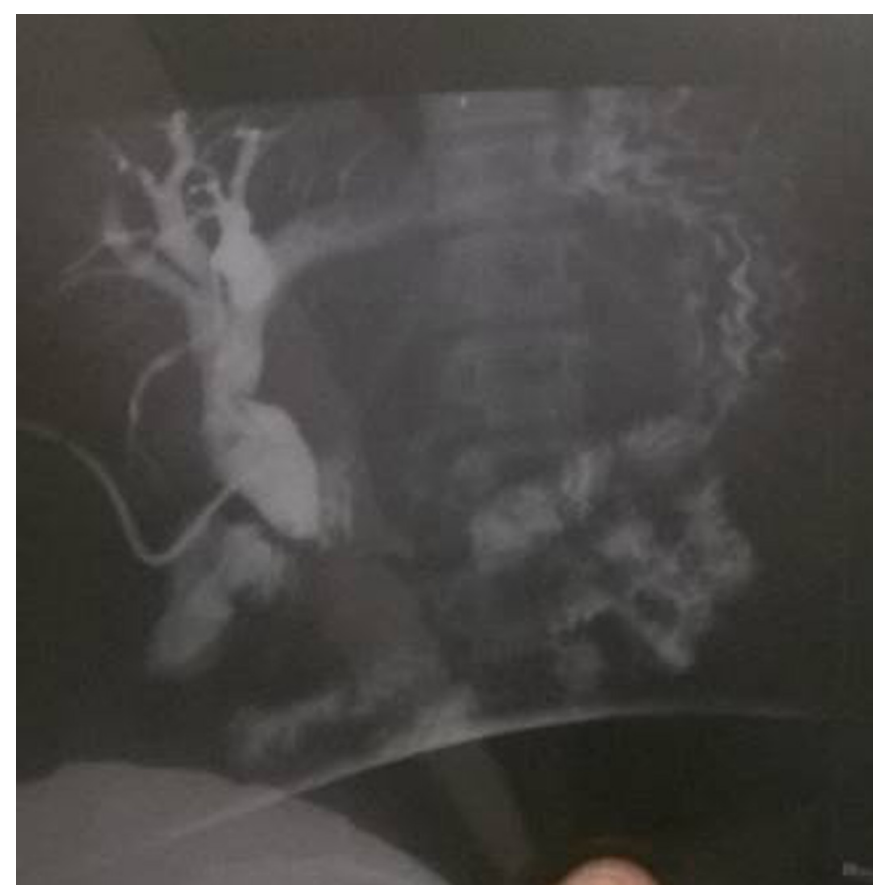

Figure 5 Cholangiograms after clamping T-tube for 8 weeks, 3.5 months postoperative, asymptomatic, no jaundice and normal bilirubin levels. Drain was thereafter removed. diagnosis is made only during laparotomy as was the case in our patient. ${ }^{1319-21}$

US is the favored initial study for patients with abdominal symptoms and jaundice; however, ERCP is the procedure of choice in patients with biliary obstruction, especially if the US findings are equivocal. ${ }^{22}$ Our patient only had a US and did not have an ERCP prior to surgery owing to resource limitations. Endoscopic ultrasonography can also be useful in non-obstructive forms. ${ }^{132324}$

There are few reports of AP presenting as obstructive jaundice in the literature, as most reports of biliary stasis are attributed to malignancies. ${ }^{14}$ This makes the present case one of the few encountered and the only case in this pediatric age group presenting with biliary obstruction in such a resource-limited environment.

The symptomatic, obstructing AP has been treated surgically. The preferred treatment is a bypass operation, such as gastrojejunostomy or duodenojejunostomy, but some authors have treated by division of the annulus with transverse duodenoplasty, duodenoduodenostomy or Whipple's procedure, depending on the intraoperative findings. 132025

Previous attempts at resection or division of the annulus $^{26}$ resulted in many complications, such as duodenal leak, pancreatitis and pancreatic fistula. The current practice is to bypass the annular constriction by duodenoduodenostomy or duodenojejunostomy from the proximal duodenal bulb to the jejunum. ${ }^{9} 13$ We performed a diamond-shaped duodenoduodenostomy with tapering of proximal duodenum to minimize anastomotic dysfunction and prolonged obstruction from dilated proximal duodenum, ${ }^{14}$ although proximal duodenal dilation usually resolves after relief of the obstruction. ${ }^{2}$

Obstructive jaundice may not only be caused by an AP (on long-standing obstruction from biliary stones can be found concurrently with AP). Other causes may include carcinoma of the ampulla of Vater, pancreaticobiliary maljunction, choledochal cyst, anomalous junction of the pancreatic and CBDs, aberrant biliary ducts, pancreas divisum, multiple communicating intrahepatic and extrahepatic duct cysts, Caroli disease, pancreaticobiliary abnormalities associated with situs anomalies and aberrant pancreatic ducts associated with enteric duplication cysts. $^{1427-29}$

The treatments are controversial and vary with the associated anomaly. They include Whipple's procedure, pancreaticoduodenectomy, duodenoduodenostomy, portal jejunostomy transduodenal sphincteroplasty, duodenojejunostomy, gastrojejunostomy, subtotal gastrectomy and others. 192028

Close, long-term follow-up after treatment for AP is necessary because some patients develop complications, such as jaundice, upper GI motility disorder, failure to thrive and chronic diarrhea. ${ }^{30}$ We shall continue to follow up the patient and to request postoperative biochemistry on subsequent, long-term follow-up reviews. 
This is a rare case of AP presenting as obstructive jaundice in an adolescent. The resource-limited setting presented unique challenges owing to limitations in available workup and treatment options.

\section{Author affiliations}

${ }^{1}$ Department of Surgery, Pediatric Surgery Unit, Mbarara University of Science and Technology, Mbarara, Uganda

${ }^{2}$ Department of Surgery, Kabale University School of Medicine, Kampala, Uganda ${ }^{3}$ Department of Surgery, Division of Pediatric Surgery, University of Massachusetts, UMass Memorial Medical Center, Massachusetts, New England, USA

${ }^{4}$ Department of Surgery, Makerere University College of Health Sciences, Kampala, Uganda

${ }^{5}$ Department of Surgery, Mulago National Referral Hospital, Kampala, Uganda ${ }^{6}$ Department of Surgery, Saint Louis University, Missouri, Midwestern region, USA ${ }^{7}$ Department of Surgery, University of California San Francisco, Calfornia, California, USA

Contributors F0, MC and DO contributed to conception and design, the acquisition of data or analysis and interpretation of data, drafting the article or revising it critically for important intellectual content, final approval of the version published, agreement to be accountable for the article and to ensure that all questions regarding the accuracy or integrity of the article are investigated and resolved. A0, AMN, NK, JS, and GV contributed to the acquisition of data or analysis and interpretation of data.

Funding The authors have not declared a specific grant for this research from any funding agency in the public, commercial or not-for-profit sectors.

Competing interests None declared.

Patient consent for publication Parental/guardian consent obtained.

Ethics approval Ethical approval was obtained from Mbarara University research ethics committee (\# 31/05-20).

Provenance and peer review Not commissioned; externally peer reviewed.

Data availability statement All data relevant to the study are included in the article or uploaded as supplementary information.

Open access This is an open access article distributed in accordance with the Creative Commons Attribution Non Commercial (CC BY-NC 4.0) license, which permits others to distribute, remix, adapt, build upon this work non-commercially, and license their derivative works on different terms, provided the original work is properly cited, appropriate credit is given, any changes made indicated, and the use is non-commercial. See: http://creativecommons.org/licenses/by-nc/4.0/.

ORCID iD

Felix Oyania http://orcid.org/0000-0003-4773-7790

\section{REFERENCES}

1 Kilbride $\mathrm{H}$, Castor $\mathrm{C}$, Andrews W. Congenital duodenal obstruction: timing of diagnosis during the newborn period. $J$ Perinatol 2010;30:197-200.

2 Aguayo P, Ostlie DJ. Duodenal and Intestinal Atresia and Stenosis. In: Holcomb G, Murphy JP, eds. Ashcraft's Pediatric Surgery. Philadelphia: Saunders Elsevier, 2010: 400-15.

3 Ameh EA, Bickler SW, Lakhoo K. Paediatric surgery: a comprehensive text for Africa. Lymphangiomas 2011;110:648-56 https://storage.googleapis.com/global-help-publications/books/ help_pedsurgeryafrica00introductionspedsurgeryafrica00introdu ctions.pdf

4 Millar AJ, Rode H, Cywes S. Intestinal atresia and stenosis. In: Ashcraft K, ed. Pediatric surgery chap 30. Philadelphia: Saunders, 2000: 3. 406-24.
5 Holcomb GW, Murphy JP, Ostlie DJ. Ashcraft's Pediatric Surgery E-Book. 6th edition. Elsevier Health Sciences, 2014.

6 Mattei P. Fundamentals of pediatric surgery. In: Mattei P, ed. Fundamentals of pediatric surgery. New York: Springer-Verlag, 2011: 355-7.

7 Mahdi B, Selim S, Hassen T, et al. A rare cause of proximal intestinal obstruction in adults - annular pancreas: a case report. Pan Afr Med $J$ 2011;10:56

8 Bouassria A, Elbouhaddouti $\mathrm{H}$, Mouaqit O, et al. Annular pancreas producing duodenal obstruction: a case report. Open $J$ Gastroenterol 2013;03:202-4.

9 Zyromski NJ, Sandoval JA, Pitt HA, et al. Annular pancreas: dramatic differences between children and adults. J Am Coll Surg 2008;206:1019-25.

10 Ohno Y, Kanematsu T. Annular pancreas causing localized recurrent pancreatitis in a child: report of a case. Surg Today 2008;38:1052-5.

11 Whittingham-Jones PM, Riaz AA, Clayton G, et al. Annular pancreas - a rare cause of gastric obstruction in an 82-year-old patient. Ann $R$ Coll Surg Engl 2005;87:13-15.

12 Dharmsathaphorn K, Burrell M, Dobbins J. Diagnosis of annular pancreas with endoscopic retrograde cholangiopancreatography. Gastroenterology 1979;77:1109-14.

13 Alahmadi R, Almuhammadi S. Annular pancreas: a cause of gastric outlet obstruction in a 20-year-old patient. Am J Case Rep 2014:15:437-40.

14 Benger JR, Thompson MH. Annular pancreas and obstructive jaundice. Am J Gastroenterol 1997;92:7013-4.

15 von EA. Bildungsfehler des pancreas und des Herzens. Ztschr F Rat Med 1862;14:354 https://ci.nii.ac.jp/naid/10016077643/

16 Shirkhoda A, Borghei P. Anomalies and anatomic variants of the pancreas. In: Textbook of gastrointestinal radiology. Elsevier 2008: 1869-84. https://www.webcir.org/revistavirtual/articulos/ marzo13/usa/usa_radiology.pdf

17 Fu PF, Yu JR, Liu XS, et al. Symptomatic adult annular pancreas: report of two cases and a review of the literature. Hepatobiliary Pancreat Dis Int 2005;4:468-71.

18 Tolia V, Rao R, Klein M. Annular pancreas. J Pediatr 1997;131:14-15.

19 Foo FJ, Gill U, Verbeke CS, et al. Ampullary carcinoma associated with an annular pancreas. JOP 2007;8:50-4.

20 Urayama S, Kozarek R, Ball T, et al. Presentation and treatment of annular pancreas in an adult population. Am J Gastroenterol 1995;90:995-9.

21 Oyania F, Ogwal A, Nimanya S, et al. Long term bowel function after repair of anorectal malformations in Uganda. J Pediatr Surg 2020:55:1400-4.

22 Ogulin M, Jamar B. Annular pancreas causing extrahepatic biliary obstruction. Radiol Oncol 2004;38:323-7 https://www.radioloncol. com/index.php/ro/article/view/1322

23 Kandpal H, Bhatia V, Garg P, et al. Annular pancreas in an adult patient: diagnosis with endoscopic ultrasonography and magnetic resonance cholangiopancreatography. Singapore Med $J$ 2009:50:e29-31.

24 Zeineb M, Sadri BA, Nizar M, et al. Annular pancreas intra operatively discovered: a case report. Clin Pract 2011;1:172-3.

25 Ravitch MM. The pancreas in infants and children. Surg Clin North Am 1975;55:377-85.

26 Thomford NR, Knight PR, Pace WG, et al. Annular pancreas in the adult: selection of operation. Ann Surg 1972;176:159-62.

27 Rizzo RJ, Szucs RA, Turner MA. Congenital abnormalities of the pancreas and biliary tree in adults. Radiographics 1995;15:49-68.

28 Komura J, Yano H, Tanaka Y, et al. Annular pancreas associated with pancreaticobiliary maljunction in an infant. Eur J Pediatr Surg 1993;3:244-7.

29 Tewari M, Verma A, Shukla HS. Carcinoma of the ampulla of Vater associated with annular pancreas. Indian J Surg 2016;78:409-10.

30 Lin YT, Chang MH, Hsu HY, et al. A follow-up study of annular pancreas in infants and children. Zhonghua Min Guo Xiao Er Ke Yi Xue Hui Za Zhi 1998;39:89-93. 